\title{
Strong armies, slow adaptation: civil- military relations and diffusion of military power
}

Article

Published Version

Kadercan, B. (2014) Strong armies, slow adaptation: civilmilitary relations and diffusion of military power. International Security, 38 (3). pp. 117-152. ISSN 1531-4804 doi: https://doi.org/10.1162/ISEC_a_00146 Available at https://centaur.reading.ac.uk/36163/

It is advisable to refer to the publisher's version if you intend to cite from the work. See Guidance on citing.

Published version at: http://muse.jhu.edu/journals/international_security/v038/38.3.kadercan.pdf

To link to this article DOI: http://dx.doi.org/10.1162/ISEC_a_00146

Publisher: MIT Press

All outputs in CentAUR are protected by Intellectual Property Rights law, including copyright law. Copyright and IPR is retained by the creators or other copyright holders. Terms and conditions for use of this material are defined in the End User Agreement.

www.reading.ac.uk/centaur

\section{CentAUR}


Central Archive at the University of Reading

Reading's research outputs online 


\section{PROJECT MUSE*}

\section{Strong Armies, Slow Adaptation: Civil-Military Relations and the Diffusion of Military Power}

Burak Kadercan

International Security, Volume 38, Number 3, Winter 2013/2014, pp.

117-152 (Article)

Published by The MIT Press

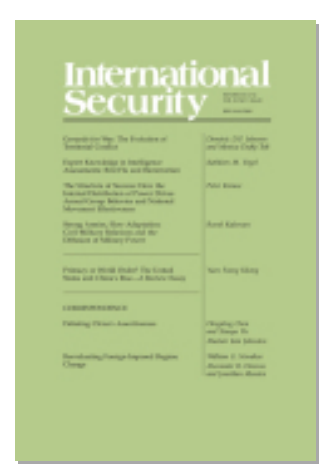

$\Rightarrow$ For additional information about this article

http://muse.jhu.edu/journals/ins/summary/v038/38.3.kadercan.html 


\title{
Strong Armies, Slow Adaptation
}

\author{
Civil-Military Relations and the Diffusion \\ of Military Power
} more willing to adopt military innovations than others? ${ }^{1}$ Why, for example, were the great powers of Europe able to successfully reform their military practices to better adapt to and participate in the so-called military revolution of the sixteenth and seventeenth centuries while their most important extraEuropean competitor, the Ottoman Empire, failed to do so $?^{2}$ The conventional wisdom suggests that cultural factors, including religious beliefs and a misplaced sense of superiority, blinded Ottoman rulers to the utility of innovations stemming from this military revolution, which involved radical changes in military strategy and tactics. ${ }^{3}$ The implication is that these rulers were almost suicidal, resisting military reforms until the early nineteenth century despite suffering continuous defeats for more than two hundred years. Such thinking follows not from a close reading of the historical and sociological literature on the Ottoman Empire, but from an Orientalist view of non-Western

Burak Kadercan is Lecturer in the Department of Politics and International Relations at the University of Reading in the United Kingdom.

The author would like to thank Jonathan Andrew Boyd, Austin Knuppe, and Charles Lipson, as well as participants in the Program on International Politics, Economics, and Security at the University of Chicago and in the Politics and International Relations Research Seminar Series at the University of Reading, for their exceptionally detailed and helpful comments on earlier drafts of this article.

1. I follow Stephen Peter Rosen in his definition of military innovation as "a new way of war, with new ideas of how the components of the organization relate each other and to the enemy, and new operational procedures conforming to those ideas." See Rosen, "New Ways of War: Understanding Military Innovation," International Security, Vol. 13, No. 1 (Summer 1988), p. 134. See also Adam Grissom, "The Future of Military Innovation Studies," Journal of Strategic Studies, Vol. 29, No. 5 (October 2006), pp. 905-934. For an overview of the literature on the diffusion of military power, see Michael C. Horowitz, The Diffusion of Military Power: Causes and Consequences for International Politics (Princeton, N.J.: Princeton University Press, 2010), pp. 18-23.

2. Michael Roberts, The Military Revolution, 1560-1660: An Inaugural Lecture Delivered before the Queen's University of Belfast (Belfast: Boyd, 1955); Geoffrey Parker, The Military Revolution: Military Innovation and the Rise of the West, 1500-1800 (New York: Cambridge University Press 1988); Clifford J. Rogers, The Military Revolution Debate: Readings on the Military Transformation of Early Modern Europe (Boulder, Colo.: Westview, 1995); and Jeremy Black, A Military Revolution? Military Change and European Society, 1550-1800 (Atlantic Highlands, N.J.: Humanities, 1991).

3. See, for example, Paul M. Kennedy, The Rise and Fall of the Great Powers: Economic Change and Military Conflict from 1500 to 2000 (New York: Random House, 1987), p. 12; E.L. Jones, The European Miracle: Environments, Economies, and Geopolitics in the History of Europe and Asia (Cambridge: Cambridge University Press, 1987), p. 181; and Bernard Lewis, The Muslim Discovery of Europe (London: Phoenix, 2003), p. 301. 
political organizations that plagues not only international relations theory but also military history. ${ }^{4}$

In this article, I offer an alternative explanation for both the inability of the Ottoman state to initiate extensive and timely military reforms and the relative ease with which European states did so that highlights the importance of civil-military relations and historical timing. ${ }^{5}$ In the Ottoman Empire, the emergence of an institutionally strong and internally cohesive army during the early stages of state formation-in the late fourteenth century-equipped the military with substantial bargaining powers. In contrast, the great powers of Europe developed similar armies only by the second half of the seventeenth century, limiting the bargaining leverage of European militaries over their rulers. In essence, the Ottoman standing army was able to block reform efforts that it believed challenged its parochial interests. Absent a similar institutional challenge, European rulers initiated military reforms and motivated officers and military entrepreneurs to participate in the ongoing military revolution.

As part of their state-consolidation efforts during the fourteenth century, Ottoman rulers created a strong, permanent central army, the heart of which was composed of the Janissaries (new soldiers). To ensure loyalty only to the sultan, the Ottoman rulers institutionalized mechanisms involving military recruitment, socialization, and career advancement that then created a strong corporate identity within the corps, an identity grounded in an extreme form of group cohesion. These mechanisms allowed the Ottoman standing army to perform remarkably well against internal and external rivals of the House of Osman from the fourteenth to the sixteenth centuries. They also allowed the Janissaries to define and defend their parochial interests, and to bargain with the sultan. Whenever the Janissaries perceived a threat to their corporate interests and privileges, they blocked military reforms not only within the corps but elsewhere in the Ottoman military establishment. Only in 1826, following the destruction of Janissary corps, did the Ottoman state begin to initiate structural military reforms.

4. Turan Kayaoḡlu, "Westphalian Eurocentrism in International Relations Theory," International Studies Review, Vo. 12, No. 2 (June 2010), pp. 193-217; and Patrick Porter, Military Orientalism: Eastern War through Western Eyes (New York: Columbia University Press, 2009). See also Daniel Goffman, The Ottoman Empire and Early Modern Europe (Cambridge: Cambridge University Press, 2002), pp. 4-6; and Suraiya Faroqhi, The Ottoman Empire and the World around It (London: I.B. Tauris, 2004).

5. Paul Pierson, Politics in Time: History, Institutions, and Social Analysis (Princeton, N.J.: Princeton University Press, 2004). 
In contrast, the great powers of Europe did not establish comparable armies until the mid-seventeenth century and fought most of their wars before then with foreign mercenaries or seasonal troops. Even when some of these states accelerated their efforts to build strong central armies, as epitomized in Louis XIV's France, their recruitment, socialization, and career advancement strategies inhibited the development of a strong corporate identity. These strategies then limited the extent to which European militaries could negotiate with civilian authorities over their parochial interests.

The result was a system where European rulers were, in general, able to implement military reforms without significant interference from the military establishment. In fact, the lack of group cohesion in the military encouraged competition among individual officers and military entrepreneurs to gain rulers' favor, for therein lay their prospects for career advancement. This competition, in turn, created strong incentives to experiment with new technologies and tactics to increase battlefield effectiveness. The French Revolution changed the ways in which European states approached recruitment, socialization, and career advancement processes in the army by introducing mass conscription, nationalistic indoctrination, and an emphasis on meritocracy (especially within the officer corps). ${ }^{6}$ By then, civilian institutions had already consolidated their authority, limiting the extent to which European militaries could exert decisive pressure on states' decisions over the production of military power.

In addition to contributing to the debate on the diffusion of military power, this article offers a blueprint of a theoretical framework that highlights the origins and consequences of the armed forces' bargaining power in different institutional settings. Moreover, the historical analysis reveals insights into the role that military entrepreneurs, mercenaries, and seasonal troops played in the evolution of the modern European state. Finally, until recently, mainstream international relations theorists either have treated extra-Westphalian casescases that remain outside the geographical and temporal scope of the so-called modern state system - as an afterthought or deferred to regional specialists and postcolonial scholars across different disciplines. The last decade, however, has seen a growing interest among international relations scholars in the study of extra-Westphalian histories, signaling a changing tide. ${ }^{7}$ An aim of this

6. Barry R. Posen, "Nationalism, the Mass Army, and Military Power," International Security, Vol. 18, No. 2 (Fall 1993), pp. 80-124.

7. Victoria Tin-bor Hui, War and State Formation in Ancient China and Early Modern Europe (New York: Cambridge University Press, 2005); and John A. Ferejohn and Frances McCall Rosenbluth, War and State Building in Medieval Japan (Redwood City, Calif.: Stanford University Press, 2010). 
article is to contribute to this expanding literature with a comparative examination of the association between the civil-military relations and production of military power in the Ottoman Empire and early modern Europe through the lens of international relations theory. The comparative approach, in turn, generates insights into not only the Ottoman case, but also the European one.

The remainder of this article is organized into six sections. First, I lay out the central puzzle within the context of debates on the diffusion of military power. Second, I outline the theoretical framework. The third and fourth sections consider the Ottoman and European cases, respectively. The fifth section addresses potential criticisms. In the conclusion, I highlight the contributions of the article to the study of civil-military relations, private military forces, and comparative historical analysis.

\section{Why Did the Ottomans "Miss" the Military Revolution?}

The historian Michael Roberts first spoke of the concept of a military revolution in a lecture delivered in $1955 .{ }^{8}$ The term originally referred to structural changes in military tactics as well as the introduction of systematic drills that followed the increasing reliance on firepower and the expansion in the size of armies, all occurring within the period 1560 to 1660. In 1988, the military historian Geoffrey Parker expanded the scope of this revolution from 1500 to 1800, heavily emphasizing the role of military technology. ${ }^{9}$ Parker cited trace italienne - a fortification style built on the concept of a bastioned fortress that proved resilient to cannon fire-and advances in gunpowder weaponry as the most important components of the revolution. His interpretation has been criticized by numerous military historians for its technological determinism and its temporal overreach. ${ }^{10}$ Here, I use the term "military revolution" with an

8. The term has been invoked not only by military historians but also by sociologists and political scientists. See, for example, Gábor Ágoston, Guns for the Sultan: Military Power and the Weapons Industry in the Ottoman Empire (Cambridge: Cambridge University Press, 2005), p. 5; Charles Tilly, Coercion, Capital, and European States, A.D. 990-1990 (Oxford: Basil Blackwell, 1990); Brian M. Downing, The Military Revolution and Political Change: Origins of Democracy and Autocracy in Early Modern Europe (Princeton, N.J.: Princeton University Press, 1992); Bruce D. Porter, War and the Rise of the State: The Military Foundations of Modern Politics (New York: Free, 1994); and Keith Krause, Arms and the State: Patterns of Military Production and Trade (Cambridge: Cambridge University Press, 1992).

9. Parker, The Military Revolution. For an earlier broadening of the scope of this term, see Geoffrey Parker, "The 'Military Revolution,' 1560-1660-A Myth?" Journal of Modern History, Vol. 48, No. 2 (June 1976), pp. 195-214.

10. Ágoston, Guns for the Sultan, p. 5; and Black, A Military Revolution. 
emphasis on reforms in tactics and force deployment that aimed to accommodate the armies' increasing reliance on firearms, as well as the standardization of training and institutionalization of drills roughly from the mid-sixteenth century until the end of the seventeenth century. ${ }^{11}$ I do so without resort to a deterministic understanding that overemphasizes the role of technology in the revolution. ${ }^{12}$

While scholars disagree about the particularities of the military revolution, ${ }^{13}$ they agree that it was an exclusively European affair. ${ }^{14}$ In this context, the Ottoman case constitutes a puzzle for three reasons. First, unlike comparable polities in China or Japan, the Ottomans were not isolated from European influences, including military advances. ${ }^{15}$ Second, neither the Ottomans' financial and organizational backwardness nor lack of logistical infrastructure prevented the empire from reforming its military institutions during the sixteenth and seventeenth centuries. In military historian Jeremy Black's words, the "[Ottomans'] military system was the most sophisticated in sixteenth-century Europe."16 Third, when the military revolution started to have a decisive impact on Western warfare by the late sixteenth century, the Ottomans had already established an impressive record of keeping up with military innova-

11. Although military historians do not agree on the utility of Parker's periodization, which traces the military revolution from 1500 to 1800, they-almost universally-recognize the importance of the period from the mid-sixteenth century to the end of the seventeenth century for the military reforms in Europe. Also, note that reform and innovation are not synonyms; reform subsumes innovation. See Christopher Tuck, "'All Innovation Leads to Hellfire': Military Reform and the Ottoman Empire in the Eighteenth Century," Journal of Strategic Studies, Vol. 31, No. 3 (June 2008), pp. 467-502.

12. In addition, the Ottomans did not have much difficulty until the eighteenth century in keeping up with the technological advances being made in Europe. See Ágoston, Guns for the Sultan.

13. Black, A Military Revolution; and William R. Thompson and Karen Rasler, "War, the Military Revolution(s) Controversy, and Army Expansion: A Test of Two Explanations of Historical Influences on European State Making," Comparative Political Studies, Vol. 32, No. 1 (February 1999), pp. 3-31.

14. William Hardy McNeill, The Pursuit of Power: Technology, Armed Force, and Society since A.D. 1000 (Chicago: University of Chicago Press, 1982); and John A. Lynn, "The Evolution of Army Style in the Modern West, 800-2000," International History Review, Vol. 18, No. 3 (August 1996), pp. 514. 15. Donald Quataert, The Ottoman Empire, 1700-1922 (New York: Cambridge University Press), p. 6; Rhoads Murphey, “Ottoman Military Organisation in South-Eastern Europe, c. 1420-1720," in Frank Tallett and D.J.B. Trim, eds., European Warfare, 1350-1750 (Cambridge: Cambridge University Press, 2010), p. 289; and Daniel Goffman, "Negotiating with the Renaissance State: The Ottoman Empire and the New Diplomacy," in Virginia H. Aksan and Goffman eds., The Early Modern Ottomans: Remapping the Empire (Cambridge: Cambridge University Press, 2007), pp. 61-74.

16. Jeremy Black, European Warfare, 1660-1815 (New Haven, Conn.: Yale University Press, 1994), p. 12; Gábor Ágoston, "Military Transformation in the Ottoman Empire and Russia, 1500-1800," Kritika: Explorations in Russian and Eurasian History, Vol. 12, No. 2 (Spring 2011), p. 290; and Rhoads Murphey, Ottoman Warfare, 1500-1700 (New Brunswick, N.J.: Rutgers University Press, 1999). 
tions. ${ }^{17}$ "Ottomans in the early modern era," writes Rhoads Murphey, "may be more accurately and appropriately regarded as active participants in a shared technology rather than as passive recipients of borrowed means and methods," 18 who also "managed to produce original concepts and practices that were, in turn, imitated by the Europeans." 19

So, how do scholars explain the Ottomans' much-delayed response to the military reforms implemented in Europe? Only a limited number of studies are available that directly deal with this question. ${ }^{20}$ The international relations literature, in turn, points toward four potential answers that fall into the following categories: cultural, neorealist, capacity oriented, or domestic politics. A cultural explanation argues that Islam-specifically, religious conservatism and an unshakable belief in the superiority of their civilization-blinded the Ottomans to the need for military reforms. ${ }^{21}$ This focus on cultural determinism is, at best, misleading. As Murphey observes, reducing Ottomans' attitudes toward political and military matters to "spiritual motives such as the triumph of Islam is a crude oversimplification of Ottoman thinking."22 Ottoman rulers did not differ much from their European counterparts when reacting to political and military challenges and opportunities, usually selecting the most expedient policies and strategies, only to later frame them in religious terms. ${ }^{23}$ Religion or religious affinities, for example, hardly deterred the

17. See, for example, Günhan Börekçi, "A Contribution to the Military Revolution Debate: The Janissaries' Use of Volley Fire during the Long Ottoman-Habsburg War of 1593-1606 and the Problem of Origins," Acta Orientalia Academiae Scientiarum Hungaricae, Vol. 59, No. 4 (December 2006), pp. 407-438.

18. Murphey, Ottoman Warfare, p. 108.

19. Mesut Uyar and Edward J. Erickson, A Military History of the Ottomans: From Osman to Atatürk (Santa Barbara, Calif.: Praeger Security International/ABC-CLIO, 2009), p. 66. Furthermore, as Karen Barkey documents, the Ottomans were very flexible when it came to institutional design and adaptation. See Barkey, Empire of Difference: The Ottomans in Comparative Perspective (Cambridge: Cambridge University Press, 2008).

20. Parker, for example, spends just three pages on the Ottoman failure to adopt European military innovations, tying it to factors such as the Ottomans' preference for big artillery and inability to learn the value of thin lines in pitched battle, factors that he leaves unexplained. Another factor Parker cites is "metallurgical inferiority." See Parker, The Military Revolution, pp. 126-128. For a rare study on the eighteenth century, see Tuck, "'All Innovation Leads to Hellfire.'” For a recent economics-oriented approach, see Philip T. Hoffman, “Prices, the Military Revolution, and Western Europe's Advantage in Violence," Economic History Review, Vol. 64, No. 1 (February 2011), pp. 39-59.

21. See, for example, Kennedy, The Rise and Fall of the Great Powers, p. 12; Jones, The European Miracle, p. 181; and Lewis, The Muslim Discovery of Europe, p. 301.

22. Murphey, Ottoman Warfare, pp. 1, 13-14.

23. Faroqhi, The Ottoman Empire and the World around It. See also Murphey, Ottoman Warfare, p. 144; Gábor Ágoston, "Information, Ideology, and Limits of Imperial Policy: Ottoman Grand Strategy in the Context of Ottoman-Habsburg Rivalry," in Aksan and Goffman, The Early Modern Ottomans: 
Ottomans from importing military technology from the European states or forming alliances with them. ${ }^{24}$

According to neorealists, competition in an anarchic system motivates actors to emulate successful self-help strategies. ${ }^{25}$ In this reading, European states of the sixteenth and seventeenth centuries co-constituted an exceptionally competitive environment and thus were compelled to emulate strategies that proved successful for state survival. Conversely, states lacking geopolitical competitors experienced less progress. The neorealist interpretation of the diffusion of military power is parsimonious and has considerable explanatory power. For example, having consolidated their domestic authority by the sixteenth century, ${ }^{26}$ Japanese rulers could take advantage of their geopolitical safety and forego significant military reform until Commodore Matthew Perry famously (or infamously) displayed U.S. naval prowess at the gates of Tokyo Bay in 1853. Faced with the threat of subjugation by a militarily superior state, Japan launched a nationwide program for economic, political, and military reformation. ${ }^{27}$ This explanation cannot account for the Ottomans' slow pace of military reforms. If anything, geography exposed the Ottoman state to threats and challenges from European powers in the West, Mamluks (until 1517) and Safavis in the East, the Russian Empire in the North, and naval powers such as Venice in the Mediterranean, not to mention rival families from within Anatolia such as Karamanogulları. Furthermore, the geopolitical pressures on the Ottomans only increased from the sixteenth century onward with the rise of the modern state form in Europe.

A third potential explanation can be derived from Michael Horowitz's

Remapping the Empire, pp. 76-77; Gábor Ágoston, “Empires and Warfare in East-Central Europe, 1550-1750: The Ottoman-Habsburg Rivalry and Military Transformation," in Tallett and Trim, European Warfare, 1350-1750, p. 114; Jakub J. Grygiel, Great Powers and Geopolitical Change (Baltimore, Md.: Johns Hopkins University Press, 2006), p. 93; and Quataert, The Ottoman Empire, 1700-1922, pp. 18-19. For a sophisticated critique of this view, see Murat Dağlı, "The Limits of Ottoman Pragmatism," History and Theory, Vol. 52, No. 2 (May 2013), pp. 194-213.

24. Ágoston, Guns for the Sultan, documents the interaction between the Ottomans and the European states regarding military technology. The Franco-Ottoman alliance that began in 1536 and lasted, if intermittently, until the Napoleonic Wars stands as a testimony to the willingness of Ottoman rulers to ally with Christian powers for pragmatic purposes.

25. Kenneth N. Waltz, Theory of International Politics (Reading, Mass.: Addison-Wesley, 1979); Posen, "Nationalism, the Mass Army, and Military Power"; and João Resende-Santos, Neorealism, States, and the Modern Mass Army (New York: Cambridge University Press, 2007). For a neorealist interpretation of the Ottoman case that also incorporates domestic variables, see Tuck, "'All Innovation Leads to Hellfire.'"

26. Parker, The Military Revolution, p. 140.

27. Peter Allan Lorge, The Asian Military Revolution: From Gunpowder to the Bomb (Cambridge: Cambridge University Press, 2008), pp. 45-65; and David B. Ralston, Importing the European Army: 
"adoption capacity" theory, which aims to explain the variation in states' responses to military innovations and the consequences of such responses for international politics. ${ }^{28}$ Horowitz writes, "It is the interaction of the resource mobilization challenges and organizational changes required to adopt the new innovation, and the capacity of states to absorb these demands, that explains both the system-level distribution of responses and the choices of individual states." ${ }^{29}$ If state capabilities and the financial costs as well as organizational change required for the internalization of the innovation are mismatched, then the state will not be able to adopt the innovation in a timely fashion. ${ }^{30}$

Horowitz's theory would perform well if the intention here were to explain the Ottoman failure to adopt particular innovations associated with nineteenth-century modern warfare. Given the failing finances of the Ottoman Empire in the nineteenth century, raising and sustaining a mass army as well as completely remaking the military's command and control structure on the basis of a rational-bureaucratic model developed in the West was simply beyond the reach of the state. The technological gap that skyrocketed as a result of the industrial revolution in Europe further added to the Ottoman inability to adopt the military innovations being made in the West. ${ }^{31}$ What makes the Ottoman case puzzling, however, is not why the Ottomans could not adapt to the changing environment by the nineteenth century, when they had already fallen behind their European counterparts, but why they did not reform in the sixteenth and seventeenth centuries, when they easily could have. As mentioned above, the Ottomans possessed the financial capacity to make improvements during this period. ${ }^{32}$ Furthermore, from an organizational perspective, the Janissary corps-disciplined infantrymen specializing in firearms ${ }^{33}$ could have provided the perfect organizational raw material (or "capital" in

The Introduction of European Military Techniques and Institutions into the Extra-European World, 16001914 (Chicago: University of Chicago Press, 1990), pp. 142-172.

28. Horowitz, The Diffusion of Military Power. Note that Horowitz does not directly address the military revolution debate.

29. Ibid., p. 3.

30. Ibid., pp. 41-42.

31. On these transformations in Europe, see Michael Howard, War in European History (London: Oxford University Press, 1976).

32. Rhoads Murphey, Studies on Ottoman Society and Culture, 16th-18th Centuries (Burlington, Vt.: Ashgate, 2007), p. 291; and Ágoston, "Military Transformation in the Ottoman Empire and Russia, 1500-1800," p. 287.

33. Janissaries were among the very first army units in Europe to use individual firearms. See John F. Guilmartin Jr., "The Military Revolution: Origins and First Tests Abroad," in Rogers, The Military Revolution Debate, p. 304. 
Horowitz's terminology) required for emulating and even improving on the military innovations being introduced in Europe.

I argue that domestic politics-in particular, Ottoman civil-military relations-provides the most convincing explanation for the dismally slow adoption of military advancements. ${ }^{34}$ Below, I offer a theoretical framework that puts the Ottoman and European military institutions in comparative perspective in the context of different responses to military revolution.

\section{The Military's Bargaining Power and Military Reforms}

Both the Ottoman and European responses can be explained by a unified theoretical framework built on two components. The first is a modular theory about the military's bargaining leverage over the ruler. The second component highlights the importance of historical timing for explaining the evolution of different institutions in different settings. ${ }^{35}$

\section{THE MILITARY'S BARGAINING POWER}

When the military enjoys a strong bargaining position vis-à-vis the civilian authority, it may block military reforms that would undercut its corporate privileges and interests. ${ }^{36}$ Intuitively, the more radical these reforms are, the greater the resistance they will encounter. The opposite is true when the military enjoys little bargaining power over civilian leaders. A military's bargaining leverage has two dimensions. The first is the strength of its corporate identity, or the degree to which its members define their identities and loyal-

34. The other usual suspects are the religious elites of the state, ulema, which also had substantial veto powers. The printing press, for example, was effectively prohibited within the Ottoman domains until 1729 thanks to the ulema's influence over decisions that involved management of knowledge. Note that though I highlight the importance of civil-military relations; I do not champion a monocausal understanding of macrohistorical stability and change. My argument is that the interpretation I offer explains better than the existing ones the different responses to the military revolution in the Ottoman Empire and early modern Europe.

35. In this regard, this approach is closely associated with historical institutionalism. See Orfeo Fioretos, "Historical Institutionalism in International Relations," International Organization, Vol. 65, No. 2 (April 2011), pp. 367-399.

36. For similar arguments, see Eric A. Nordlinger, Soldiers in Politics: Military Coups and Governments (Upper Saddle River, N.J.: Prentice-Hall, 1977), p. 65; Barry R. Posen, The Sources of Military Doctrine: France, Britain, and Germany between the World Wars (Ithaca, N.Y.: Cornell University Press, 1984); Jack Snyder, “Civil-Military Relations and the Cult of the Offensive, 1914-1984," International Security, Vol. 9, No. 1 (Summer 1984), pp. 108-146; and Risa Brooks, Shaping Strategy: The Civil-Military Politics of Strategic Assessment (Princeton, N.J.: Princeton University Press, 2008). 
ties with reference to the military as a distinct institution. ${ }^{37}$ The strength of this identity is, to a large extent, a function of three mechanisms: recruitment, socialization, and career advancement. In cases where selective recruitment policies are accompanied by rigorous socialization mechanisms and opportunities for recruits to advance up the ranks, the armed forces will be able to develop a strong corporate identity. The strength of this corporate identity will then allow the military to define and voice its organizational interests as a unitary actor. ${ }^{38}$ In cases where the military's corporate identity is weak, the loyalties of its members will be defined more in terms of interlocking ethnic, religious, tribal, or political affiliations as well as individual self-interest (at the expense of parochial interests of the armed forces). Under these circumstances, the armed forces will encounter difficulties in defining and defending its corporate interests.

A strong corporate identity, however, does not guarantee that the military will become a powerful political actor. Also necessary is its centrality to the political survival calculus of civilian decisionmakers. ${ }^{39}$ Intuitively, if the military occupies such a central position, it may enjoy substantial bargaining powers over these decisionmakers. An early example is the Roman Praetorian Guard, which notoriously exploited its location and centrality for the Senate-the guard was stationed in the capital and served to protect the Senate from the legions-to impose its will on Roman politicians. In modern democratic states, in contrast, the military has no such option.

Figure 1 summarizes the relationship between these two dimensions. ${ }^{40}$ Of the possible four categories, the existing literature on civil-military relations focuses on two. The first involves modern professional armies that profess a strong corporate identity but have little direct impact on leaders' political survival calculus. In this category, the military can define and voice its institutional interests, but has little bargaining power vis-à-vis the state. To be sure, the armed forces could still influence a leader's decisions, but this influence

37. For a similar line of thinking, see Stephen Peter Rosen, "Military Effectiveness: Why Society Matters," International Security, Vol. 19, No. 4 (Spring 1995), pp. 5-31.

38. My emphasis is not on the content of the organizational culture, but on its salience within the organization. On the relationship between the content of organizational culture and international behavior, see Elizabeth Kier, Imagining War: French and British Military Doctrine between the Wars (Princeton, N.J.: Princeton University Press, 1997).

39. On political survival, see Bruce Bueno de Mesquita et al., The Logic of Political Survival (Cambridge, Mass.: MIT Press, 2003).

40. For a similar approach, see Brooks, Shaping Strategy, p. 7. 
Figure 1. Armed Forces' Bargaining Power over the Civilian Arm of the State armed forces and political survival

\begin{tabular}{|c|c|c|c|}
\hline \multirow{3}{*}{$\begin{array}{l}\text { salience of } \\
\text { corporate } \\
\text { identity }\end{array}$} & & central role & peripheral role \\
\hline & strong & $\begin{array}{c}\text { veto player } \\
\text { institutionalized } \\
\text { "arm-twisting" } \\
\text { powers } \\
\text { (Ottoman Empire, } \\
\text { 1500-1826) }\end{array}$ & $\begin{array}{l}\text { professional army } \\
\text { Huntington's “ideal” } \\
\text { civil-military } \\
\text { relationship } \\
\text { (Western-style } \\
\text { modern armies) }\end{array}$ \\
\hline & weak & $\begin{array}{l}\text { volatile partner } \\
\text { unstable yet tension-ridden } \\
\text { civil-military relations, } \\
\text { risk of "colonel coups" } \\
\text { (e.g., pre-Qaddafi Libya, } \\
\text { pre-Saddam Iraq) }\end{array}$ & $\begin{array}{l}\text { insignificant other } \\
\text { inconsequential bargaining } \\
\text { leverage over the } \\
\text { civilian arm of the state } \\
\text { (European armies, } \\
1500-1789)\end{array}$ \\
\hline
\end{tabular}

will not entail twisting her arm. ${ }^{41}$ In the second category, the military lacks internal cohesion but plays a vital role as regards leaders' political survival and succession mechanisms. In this situation, the military may enjoy some bargaining power over the civilians, but given the lack of cohesion in defining and defending its corporate interests, such leverage is neither stable nor institutionalized. In some cases, some segments of the military may have strong incentives to become directly involved in politics through military interventions, setting the stage for coups and military dictatorships.

There is, however, a third category, which melds a military's strong corporate identity and central position in determining a leader's political survival prospects. Building on its centrality for leader survival, the military can establish substantial bargaining-or, arm-twisting-powers over the civilian rulers to pursue its corporate interests, which may sometimes be affiliated with policies that impede battlefield effectiveness and contradict a state's long-term security priorities. The case of the Ottoman Empire from the sixteenth century

41. Samuel P. Huntington, The Soldier and the State: The Theory and Politics of Civil-Military Relations (Cambridge, Mass.: Belknap, 1981), pp. 70-74. 
until 1826 fits this third category. In the fourth, the military enjoys neither a strong corporate identity nor a vital position with respect to leaders' political survival, depriving it of substantial bargaining powers over the civilian leadership. Europe from 1500 to 1789 falls into this category.

\section{THE IMPORTANCE OF HISTORICAL TIMING}

Variation in the level of bargaining leverage that a military enjoys over the civilian leadership owes much to historical timing. ${ }^{42}$ In this context, Thomas Ertman's groundbreaking Birth of the Leviathan offers a useful analytical framework. ${ }^{43}$ According to Ertman, some European states-for example, Francewere compelled to accelerate their state-building efforts earlier than others because of the greater geopolitical pressures they faced. Rulers who had to consolidate their states before 1450 offered a number of privileges and compromises to skilled administrators, because both the relevant knowledge and individuals who could supply it were scarce. This led to the emergence of "patrimonial administrations" where, over time, administrators acquired significant leverage vis-à-vis the government. ${ }^{44}$ Alternatively, states that accelerated their state-building efforts after 1450 enjoyed two advantages: first, much of the necessary knowledge had already been created as a result of the first wave of state consolidation and, second, the increasing number of universities and rising literacy rates expanded the pool of skilled personnel. These developments allowed subsequent state builders to establish what Ertman calls "bureaucratic administrative systems," which then constituted the backbone of so-called Weberian rational bureaucracies.

Following Ertman, I argue that "starting conditions" play a big role in how institutions-in particular, civil-military relations-evolve. ${ }^{45}$ If a military is central to the war-making efforts of the state and possesses a robust set of institutional practices and internal cohesion during the early stages of state formation, it will also possess bargaining powers over the civilian leadership. When these conditions are met, the military can succeed in "transforming the

42. See, for example, Alexander Gerschenkron, Economic Backwardness in Historical Perspective: A Book of Essays (Cambridge, Mass.: Belknap, 1962); Ronald Grigor Suny, The Revenge of the Past: Nationalism, Revolution, and the Collapse of the Soviet Union (Redwood City, Calif.: Stanford University Press, 1993); and Jack Snyder, Myths of Empire: Domestic Politics and International Ambition (Ithaca, N.Y.: Cornell University Press, 1991).

43. Thomas Ertman, Birth of the Leviathan: Building States and Regimes in Medieval and Early Modern Europe (Cambridge: Cambridge University Press, 1997).

44. Ibid., p. 5.

45. Ibid., p. 24. See also Pierson, Politics in Time. 
[positions] it occupies into the group's private patrimony rather than that of the ruler." ${ }^{46}$ The armed forces can then exploit its position within the state to emerge as a key player in a ruler's political survival calculus, empowering it with substantial arm-twisting powers. As a corollary, individual military leaders will have incentives to prioritize the military's parochial interests, for therein lie prospects for career advancement, sometimes at the expense of state's security priorities.

In cases where a strong army emerges later in the state-formation process, "rulers successfully resist the appropriating designs of their [military] elite staffs and retain the right to remove officials at will." ${ }^{\prime 7}$ As a result, the armed forces have limited impact on a ruler's political survival calculus and thus little leeway in decisions that involve their parochial interests. Under these circumstances, individual military commanders will have strong incentives to compete with each other to gain the approval of civilian rulers. Assuming that rulers' incentive structures are dominated by a concern for political survival as well as by geopolitical considerations, individual military commanders will have little incentive to pursue the parochial interests of the armed forces when such interests contradict rulers' priorities.

I argue that the differences in historical timing with respect to the emergence of central armies with strong institutional practices produced differential bargaining powers for the Ottoman and European military establishments. The Ottoman Empire "was exceptionally early in its development of an institutional framework for the military," ${ }^{\prime 8}$ and it had established a militarily and institutionally strong central army as early as the first half of the fifteenth century, more than a century before the military revolution in Europe began. The Janissary corps—“the first standing army in Europe" ${ }^{49}$ - eventually gained significant bargaining power over Ottoman rulers, blocking civilian efforts to introduce reforms from the late sixteenth century until early nineteenth century. ${ }^{50}$ In contrast, European great powers lacked central armies with substantial bargaining powers vis-à-vis the state during the military revolution, which

46. Ertman, Birth of the Leviathan, p. 8 .

47. Ibid.

48. Murphey, Ottoman Warfare, p. 49.

49. Halil Inalcik, The Ottoman Empire: The Classical Age, 1300-1600 (New York: Praeger, 1973), p. 11.

50. One common assumption about the Ottoman state is that it was "an army before it was anything else." Ralston, Importing the European Army, p. 44. This claim is hardly sustainable in the face of recent historical scholarship on the Ottoman Empire, however. See, for example, Barkey, Empire of Difference. 
allowed rulers to reform their military establishments with an eye toward the changing geostrategic environment.

\section{An Army Too Strong: The Janissaries and the Military Revolution}

When European states came of age around 1500, statesmen and scholars viewed the Ottoman Empire as a geopolitical giant. Although a transcontinental empire by 1500, the Ottoman state had humble beginnings. Unlike the Qing, Shun, or Ming dynasties in China, the Ottoman Empire had to be built from the ground up. When the House of Osman was established in 1299 on the northwestern edge of Asia Minor by a "minor march lord,"51 it was one of the smaller Turkic beyliks (emirates) in an expansive archipelago of post-Seljuk principalities and not the most likely candidate for a future regional hegemon.

By the end of the fourteenth century, however, this "insignificant frontier state" had subdued most of the emirates in the region and extended its power into Europe, ${ }^{52}$ as epitomized in the Ottomans' decisive victory over the Serbian army in Kosovo in 1389. The Ottoman expansion came to a halt in 1402, when Timur's Turco-Mongol forces defeated Beyazıd I in the Battle of Ankara, paving the way for the Ottoman Interregnum, which lasted until 1413. Surviving this near-death experience, the Ottomans established a transcontinental empire by the mid-fifteenth century, which was formalized with the conquest of Constantinople in 1453. By 1453, Black writes, "no Christian state matched Mehmed [the Conquerer's] power, and the Ottoman Empire became the most important state in Europe," ${ }^{\prime \prime 3}$ posing a military threat to Europe "that could be given a parallel and historical validation by comparison with the Persians of Antiquity." 54 The Ottomans' political and military might continued to expand. Not only did the Ottomans subdue the Mamluks of Egypt in 1517 and subsequently bring the caliphacy to Istanbul, but they also made extensive gains in Europe, most notably laying siege to Vienna in 1529. Displaying a cunning understanding of power politics, the Ottoman state emerged-during the sixteenth century-as the kind of regional hegemon that the Habsburgs and Louis XIV failed to create in Europe.

51. Metin Kunt, "State and Sultan up to the Age of Suleyman: Frontier Principality to World Empire," in Kunt and Christine Woodhead, eds., Süleyman the Magnificent and His Age: The Ottoman Empire in the Early Modern World (London: Longman, 1995), p. 4.

52. Inalcik, The Ottoman Empire, p. 3.

53. Jeremy Black, European Warfare, 1494-1660 (London: Routledge, 2002), p. 56.

54. Jeremy Black, A History of Diplomacy (London: Reaktion, 2010), p. 18. 


\section{OTTOMAN MILITARY INSTITUTIONS AND THE JANISSARIES}

The Ottomans' rise to prominence owed much to their ability to build institutions, especially in the military sphere. Initially, Ottoman military practice followed the basic principles of the Seljuk-Turcoman and Ghazi traditions, which emphasized intermittent raids (as opposed to large-scale seasonal campaigns). ${ }^{55}$ These traditions underwent rigorous institutionalization beginning in the mid-fourteenth century. During military campaigns, the Ottomans could draw on auxiliaries such as azabs ("bachelors," which referred to infantry divisions composed of seasonal troops with little training and weaponry) and akincis ("raiders," whose main role was to engage in skirmishes in the frontier areas), as well as cavalry support from the Tatar khan. To a large extent, however, the military might of the Ottomans depended on sipahis (provincial troops) and the permanent central standing army, kapıkulus (slaves of the Porte), which included the Janissaries.

The sipahis, whose ranks were filled with cavalrymen from Anatolia and the Balkans, constituted the bulk of the Ottoman fighting force. The sipahi system became prevalent in the second half of the fourteenth century, when the Ottomans began their conquest of new territories. ${ }^{56}$ The Ottoman state distributed these newly acquired territories-which were still considered state property-among commanders and soldiers according to their "merit and contribution to the conquest" as timars, or temporary land grants. ${ }^{57}$ The sipahis were then "obligated to outfit themselves and report to the battlefront" during military campaigns. ${ }^{58}$ Because they were summoned from different parts of the empire and only seasonally for large campaigns, the sipahis did not form a cohesive fighting force and lacked centralized training or socialization mechanisms. ${ }^{59}$

In contrast, the Janissary corps, which was established in the mid-fourteenth

55. Uyar and Erickson, A Military History of the Ottomans, pp. 2-8. See also Inalc1k, The Ottoman Empire, pp. 6-8, 104-118; Halil Inalcık, "The Rise of the Ottoman Empire," in Vernon J. Parry and Michael A. Cook, eds., A History of the Ottoman Empire to 1730 (Cambridge: Cambridge University Press, 1976), pp. 10-20; Kunt, "State and Sultan up to the Age of Suleyman," pp. 9-13; and John F. Guilmartin Jr., "Ideology and Conflict: The Wars of the Ottoman Empire, 1453-1606," Journal of Interdisciplinary History, Vol. 18, No. 4 (Spring 1988), pp. 726-727.

56. On how the Ottomans approached conquest, see Halil Inalc1k, “Ottoman Methods of Conquest," Studia Islamica, No. 2 (1954), pp. 103-129.

57. Uyar and Erickson, A Military History of the Ottomans, p. 17; and Vernon. J. Parry, "The Successors of Sulaiman, 1566-1617," in Parry and Cook, A History of the Ottoman Empire to 1730, pp. 104106.

58. Virginia H. Aksan, "Ottoman War and Warfare, 1453-1813," in Jeremy Black, ed., War in the Early Modern World, 1450-1815 (London: University College London Press, 1999), p. 150.

59. They also became increasingly irrelevant and ineffective from seventeenth century onward. 
century, "constituted the standing, salaried infantry of the Ottomans, starting out as the elite troops of the court." 61 As Mesut Uyar and Edward Erickson write, "[T]he Janissary Ortas [regiments] were the first permanent infantry regiments in all of Europe and were founded at least 100 years before any other example." 62 The Ottomans' initial successes on the battlefield owed much to these well-trained, experienced, and fully committed troops. ${ }^{63}$ The Janissary corps became the key component of the sultan's army, especially during the reign of Mehmed II (1451-81), who positioned the bulk of the corps within the capital, following the conquest of Constantinople. ${ }^{64}$ As Uyar and Erickson state, the Janissary corps was "an innovation at least partially driven by the need of the dynasty to counter the strength of the provincial [timar holders]" as well as semi-independent march lords. ${ }^{65}$ The Janissaries thus underpinned the domestic authority of the sultan with respect to the military or paramilitary threats coming from within the empire.

The Janissaries were not limited to countering threats to the sultan's authority. They were also involved, albeit indirectly, in the succession process. Unlike most of their European counterparts, the Ottomans practiced open succession: it was not the eldest but the fittest prince (şehzade) who was supposed to replace a deceased (or deposed) sultan. ${ }^{66}$ Given that the bulk of the corps was stationed in the capital, the Janissaries' support became a crucial component of sultans' political survival calculus and aspiring princes' political machinations in a political landscape where prospects of political survival were, at best, tenuous. ${ }^{67}$

The Janissary corps' strong corporate identity helped to cement its importance to the sultan. ${ }^{68}$ Through its recruitment, socialization, and career advancement practices, the corps fostered deep group coherence among its

See Caroline Finkel, Osman's Dream: The Story of the Ottoman Empire, 1300-1923 (New York: Basic Books, 2005), pp. 178-179.

60. The historical record is unclear about the exact date when the corps was created or the identity of the sultan who introduced it.

61. Uyar and Erickson, A Military History of the Ottomans, p. 20.

62. Ibid., p. 38.

63. Black, European Warfare, 1494-1660, p. 58.

64. Finkel, Osman's Dream, p. 77.

65. Uyar and Erickson, A Military History of the Ottomans, p. 20.

66. On succession practices of the Ottomans, see Parry, "Successors of Sulaiman, 1566-1617," p. 48; Quataert, The Ottoman Empire, 1700-1922, pp. 90-93; and Guilmartin, "Ideology and Conflict," pp. 729-730.

67. Between 1617 and 1730, for example, there were dethronements in seven out of ten reigns. See Ágoston, "Military Transformation in the Ottoman Empire and Russia, 1500-1800," p. 283.

68. I argue that, without such identity, the succession mechanisms alone would not have been sufficient for the Janissaries to gain overwhelming bargaining power over the sultans. 
members, which then allowed it to define and defend its collective interests. From 1380 onward, Janissaries were recruited through a process known as devshirme, a variant of the Mamluk practice of utilizing slave-soldiers. ${ }^{69}$ Devshirme was, in principle, "a levy of Christian male children, from 8 to 15 years old," or, more accurately, "the forced tribute of selected children from their Christian families, who were then used as military slaves after a long training period that included cultural and religious training in addition to military training." 70

According to this process, every three to five years Ottoman officials would visit a Christian territory conquered by the Ottoman forces to "collect one boy from every 40 families." 71 The children were generally taken to the capital, where they trained in palace schools. Most would then be assigned to the Janissary corps as combat troops. The logic behind this strategy was multifaceted. First, concerned with the possibility that recruits coming from a particular region or tribe could hijack the central army, the Ottomans found it expedient to transform Christian boys into Muslim subjects with no links to their native lands, which ensured their loyalty to the sultan. Second, recruitment at an early age made practical sense, because "children were more responsive to the training, and their bodies and minds were easily molded according to the needs of the military." 72

The Ottomans designed the Janissaries' socialization mechanisms to create an elite, unified military unit. The Janissaries spent their lives in their barracks (ocaks) until they retired. As a principle, they could not marry or acquire skills as artisans until they left the corps. The training process, which was long and complex, emphasized "unit cohesion and élan" designed to "create intense loyalty to the institution." ${ }^{73}$ There was no separate officer corps, and officers were appointed and promoted from within the ocaks. As a result, senior officers and regular troops continued their association, which further added to the cohesion within the Janissary corps.

These recruitment, socialization, and career advancement strategies pro-

69. Neither the slave-soldier system nor the long-term problems that such a system caused were unique to the Ottomans. See David Ayalon, Gunpowder and Firearms in the Mamluk Kingdom: A Challenge to a Mediaeval Society (London: Vallentine, Mitchell, 1956); Matthew S. Gordon, The Breaking of a Thousand Swords: A History of the Turkish Military of Samarra, A.H. 200-275/815-889 C.E. (Albany: State University of New York Press, 2001); and Hugh Kennedy, The Armies of the Caliphs: Military and Society in the Early Islamic State (London: Routledge, 2001).

70. Uyar and Erickson, A Military History of the Ottomans, p. 19.

71. Ibid.

72. Ibid.

73. Ibid. 
duced a strong corporate identity within the Janissary corps. Ultimately, however, the empire's state builders proved too successful, because, in the words of Uyar and Erickson, "the Janissaries always stood together against all other groups including, occasionally, the sultan."74 "The solidarity within the corps became very dangerous for the government," as the Janissaries discovered that they could exploit it for instigating uprisings or initiating coups. ${ }^{75}$ By the early sixteenth century, "even the presence of a forceful sultan did little to cow the Janissaries, once they perceived an infringement of their privileges or a denial of their customary rights." ${ }^{\prime 76}$ Even Süleyman I, whose reign from 1520 to 1566 is universally accepted as the apex of Ottoman power, had to contend with the Janissaries. ${ }^{77}$ The mutinous attitude of the corps, for example, prompted him to prematurely terminate the siege of Vienna in 1529.

THE JANISSARIES DURING THE MILITARY REVOLUTION

Paradoxically, the increasing influence of the Janissaries over the sultan was accompanied with their decreasing battlefield effectiveness vis-à-vis European armies, which were gradually transforming their training and tactics. The Ottomans experienced the full impact of the military reforms in Europe during the Long War (1593-1606) when they fought the Habsburgs, whose field army at the time was "comparable to the best armies of Western Europe" in tactics and use of firepower. ${ }^{78}$ The Ottomans responded to the superior tactics and force deployment strategies they encountered on the battlefield with quantitative but not qualitative modifications.

Although their numbers increased, the Janissaries failed to make changes in tactics or training. ${ }^{79}$ The increasing number of Janissaries was especially notable in the capital. The palace Janissary corps stood at 11,000-12,000 in 1527, a number that rose to 20,000 in 1567 and to 37,000 by the end of the Long War in $1606 .{ }^{80}$ This number increased to 53,849 in 1660 , with the proportion of Janissaries to all salaried staff employed by the empire rising from 32.7 percent in 1527 to 54.8 percent in 1660. From 1527 to 1660, the Janissaries accounted

74. Ibid., p. 39.

75. Ibid.

76. Murphey, Ottoman Warfare, p. 135.

77. Aksan, "Ottoman War and Warfare, 1453-1813," p. 156; and Parry, "Successors of Sulaiman, 1566-1617," p. 81.

78. Ágoston, "Military Transformation in the Ottoman Empire and Russia, 1500-1800," p. 284.

79. Ibid., pp. 284, 317; and Virginia H. Aksan, Ottomans and Europeans: Contacts and Conflicts (Istanbul: Isis, 2004), pp. 91-92, 155.

80. Aksan, “Ottoman War and Warfare, 1453-1813," p. 155. 
for 23.4 percent of payments to 46.6 percent of all state salaries. ${ }^{81}$ Given their increasing size, not to mention their weight in the state's expenditures, the Janissaries became even more important for the Ottoman rulers over the course of the seventeenth century.

Under these circumstances, the Janissaries "seized the moment [and] . . . used it to strengthen their privileges," ${ }^{82}$ resisting reforms that went against their operational and training habits. For example, despite the Ottoman rulers having been aware of the importance of systematic drill, a key component of the military revolution, the Janissaries refused to adopt it, not wanting to disrupt their traditional training practices; they even blocked its adoption by other Ottoman military units. ${ }^{83}$ A milestone was reached during the reign of Osman II, who came to power in $1618 .{ }^{84}$ Identifying the Janissaries' ineffectiveness on the battlefield and their unruliness as root causes of the empire's military decline, Osman began thinking about reforming the military. In 1622, perceiving their privileges and even their very existence to be under attack, the Janissaries reacted to Osman's yet-to-materialize plans to reform the military, forming alliances within the palace against the sultan.

The Janissaries' actions triggered a series of events that eventually led to the public humiliation of Osman at the hands of the Janissaries and his eventual assassination, neither of which a reigning sultan had ever experienced. ${ }^{85}$ Confirming the role of the Janissaries not only as king makers but also king slayers, Osman's assassination accelerated the Janissaries' grip on the state apparatus regarding issues relevant to their parochial interests. Their political prowess also extended far beyond the walls of the palace. In 1656, for example, the Janissaries initiated a major revolt in Istanbul, effectively shutting down the city in an effort to negotiate improved terms of payment and rewards from the sultan. ${ }^{86}$

81. Murphey Ottoman Warfare, pp. 16-17. For detailed statistics, see Inalcık, The Ottoman Empire, p. 83; and Ágoston, "Empires and Warfare in East-Central Europe, 1550-1750," pp. 128-129.

82. Ágoston, "Military Transformation in the Ottoman Empire and Russia, 1500-1800," p. 317.

83. Another, similar example was the Janissaries' refusal to adopt the pike and, later, the bayonet (mounted on a musket) in the sixteenth and seventeenth centuries. A major reason for this refusal was that these weapons required deployment in "close order squares and oblongs," which meant that the entire training and tactics of the Janissary corps would have needed to be reorganized. Avigdor Levy, "Military Reform and the Problem of Centralization in the Ottoman Empire in the Eighteenth Century," Middle Eastern Studies, Vol. 18, No. 3 (July 1982), p. 230.

84. Parry, "Successors of Sulaiman, 1566-1617," p. 134.

85. Finkel, Osman's Dream, p. 201.

86. Aksan, "Ottoman War and Warfare, 1453-1813," p. 161; and Finkel, Osman's Dream, pp. 248252. 
By the late seventeenth century, "the expense of maintaining [the Janissary corps] was no longer justified by the battle achievements of its members." 87 Take, for example, the Ottoman clash with the Habsburg army in the Battle of Zenta in 1697. Despite the odds-Habsburg forces were outnumbered two to one-the Ottomans suffered defeat with more than 30,000 casualties compared with 2,100 on the Habsburg side. ${ }^{88}$ The Ottomans' inferior fighting skills were again on display against the Russians, who had adopted Western military practices following Peter the Great's reforms. ${ }^{89}$ In the Battle of Kagul in 1770, for example, the Russian army's "better organized, but sick and exhausted troops dispersed an [Ottoman] army perhaps five times their number after a battle which lasted about four hours." ${ }^{90}$ According to Archduke Charles of Austria, the Ottoman defeat followed from structural deficiencies in "organization, discipline, doctrine, and command," 91 underscoring the urgent need for reforms. ${ }^{92}$

During the same period, the Janissaries were taking measures to further relax their recruitment and training standards. By the eighteenth century, Janissaries could marry while on active duty, and their sons (kulog lus) had gained favored admission to the corps, replacing the devshirme system as the main source of recruitment. ${ }^{93}$ Garrisoned in the provincial centers and the capital, the Janissaries had become a numerically large (and expensive) but largely worthless body, "strong enough to terrorize government and population alike, but too weak to defend the empire." 94 Reduced to a "part-time militia," 95 or "a fictional fighting force," brokers operating within Ottoman urban areas and becoming "the leaders or opinion makers of the urban middle class." 97 Thus, despite the Janissaries suf-

87. Murphey, Ottoman Warfare, p. 45.

88. Aksan, “Ottoman War and Warfare, 1453-1813," p. 164. Jeremy Black puts the Habsburg casualties as low as 300. See Black, Beyond the Military Revolution: War in the Seventeenth-Century World (Basingstoke, U.K.: Palgrave Macmillan, 2011), p. 131.

89. Ralston, Importing the European Army, pp. 13-42.

90. Aksan, Ottomans and Europeans, p. 105.

91. Quoted in Tuck, "'All Innovation Leads to Hellfire,'” p. 473.

92. Note that until the early eighteenth century, "Ottomans surpassed their central European contemporaries in their ability to mobilise and support large armies in the field," suggesting that primarily tactics and force deployment led to these military disasters. See Rhoads Murphey, "Ottoman Military Organization in South-Eastern Europe, c. 1420-1720," in Tallet and Trim, European Warfare, 1350-1750, p. 136.

93. Uyar and Erickson, A Military History of the Ottomans, p. 90.

94. Erik Jan Zürcher, Turkey: A Modern History (London: I.B. Tauris, 1993), p. 15.

95. Ibid.

96. Aksan, Ottomans and Europeans, p. 105.

97. Uyar and Erickson, A Military History of the Ottomans, p. 91. 
fering continuous military defeats, the sultans dared not initiate significant military reforms that would hurt the Janissaries' collective interests. Instead, they had to draw increasingly on peasant militias and provincial troopswhose military practices, in general, were inferior to those of the Janissariesfor their war efforts. Such measures, however, did not add much to the effectiveness or efficiency of the Ottoman military forces, broadly defined. ${ }^{98}$

The Janissary corps also became a source of corruption, especially during the eighteenth century, further draining the state's financial resources. The practice of "maintaining long-dead or inactive soldiers on the rolls for the sake of their salaries," for example, became the norm in the corps. ${ }^{99}$ The Janissaries' pay tickets also started to be sold as stock or bond certificates, at times acting as "a kind of replacement currency."100 Although similar problems existed in early modern Europe, ${ }^{101}$ the scope of the Janissaries' corruption was unparalleled. By the mid-to-late eighteenth century, the size of the Janissary corps had reached 400,000 on paper, but a truer number of active combat troops ranged from 20,000 to $50,000,{ }^{102}$ suggesting that the ratio of abused pay tickets to honest ones was around ten to one. ${ }^{103}$

\section{OTTOMAN ATTEMPTS AT REFORM}

The Ottomans did have some reformers, but they had to contend with the Janissary corps. ${ }^{104}$ After the devastating defeats of 1683-99 in Europe, for example, Köprülü Hüseyin Pasha reduced the number of active Janissaries from 70,000 to 34,000 , believing they were a burden to Ottoman war efforts. He also sought to increase discipline and improve training throughout the military, including among the sipahis. Faced with growing criticism, Hüseyin Pasha was sacked in 1702 and his reforms were undone, with the number of Janissary troops rising to 53,200 in a matter of months. Similarly, Mahmud I (1730-54) enlisted French nobleman and officer Claude-Alexandre Comte de Bonneval to reorganize the Corps of the Bombardiers along European lines and to in-

98. Virginia H. Aksan, "Military Reform and Its Limits in a Shrinking Ottoman World, 18001840," in Aksan and Goffman, The Early Modern Ottomans, p. 120; and Quataert, The Ottoman Empire, 1700-1922, p. 45.

99. Aksan, "Ottoman War and Warfare, 1453-1813," pp. 158-159.

100. Zürcher, Turkey, p. 15.

101. John A. Lynn, "The Trace Italienne and the Growth of Armies: The French Case," Journal of Military History, Vol. 55, No. 3 (July 1991), pp. 297-330; and John A. Lynn, "Recalculating the French Army Growth during the Grand Siècle, 1610-1715," French Historical Studies, Vol. 18, No. 4 (Autumn 1994), pp. 881-906.

102. Aksan, “Ottoman War and Warfare, 1453-1813," p. 167.

103. Aksan, Ottomans and Europeans, p. 116.

104. Posen, The Sources of Military Doctrine, refers to such individuals as "mavericks." 
crease their number from 300 to 1,000. Impressed with the new drill that Bonneval introduced to the corps, Mahmud decided to further increase the number of bombardiers to 10,000. Immediately faced with Janissary resistance, Mahmud was compelled to give up even his initial plans, and the Corps of the Bombardiers remained at just 300 men. ${ }^{105}$

The first serious attempt at structural reform began in 1792 and ended in 1807. Coming to power in 1789 , Selim III was convinced that the empire was doomed unless the military system was entirely restructured. Selim initially sought to convince the Janissaries to accept new tactics and weaponry, only to be rebuffed by them and their political allies. ${ }^{106}$ Without immediately abolishing the core Janissary corps, but with the clear intention of doing so later, Selim created the Nizam- - Cedid (New Order) corps, whose composition and structure were based on European armies. In 1806-07, the new corps numbered 25,000 men "armed with modern weapons, trained by Western European officers, and praised for their efficiency and good bearing by almost all the Europeans who observed them."107

For the Janissaries, the possibility of losing their monopoly on organized violence was unacceptable, because, as Andrew Wheatcroft states, "It was inevitable that their market value would decline, and even their basic security would be threatened." 108 In May 1807, the auxiliary contingents of the Janissary garrison in Istanbul rioted, demanding the abolition of the new corps and the heads of leading reformists. The sultan was compelled to give in to the Janissaries' demands, which included allowing the Janissaries to slaughter the members of the Nizam-1 Cedid. The fate of the military reformists and members of the Nizam-1 Cedid highlighted a peculiar dynamic: not only was there little incentive for the military commanders to experiment with or participate in military reforms, but it was also a very risky business to do so. Following the destruction of Nizam-1 Cedid, Selim was forced to give up his throne, only to be assassinated shortly afterward. To ensure that future Ottoman leaders refrained from similar reform efforts, the Janissaries convinced the state's religious authorities to issue an opinion declaring that the suggested military reforms were incompatible with religious law.

105. Levy, "Military Reform and the Problem of Centralization in the Ottoman Empire in the Eighteenth Century."

106. Stanford J. Shaw, "The Origins of Ottoman Military Reform: The Nizamı Cedid Army of Sultan Selim III," Journal of Modern History, Vol. 37, No. 3 (September 1965), p. 291.

107. Ibid., p. 302.

108. Andrew Wheatcroft, The Ottomans (London: Viking, 1993), p. 100. 
Despite enjoying significant leverage vis-à-vis Ottoman rulers, the Janissaries had become "divided into factions or small interest groups" by the nineteenth century, ${ }^{109}$ suggesting that the corps was losing its corporate identity. ${ }^{110}$ The dilution of their corporate identity, which also meant that they could no longer effectively define, voice, and defend their parochial interests as a unitary actor, eventually exposed the Janissaries to the will of the sultan. Terrified by the incompetence of the Ottoman military establishment during the War of Greek Independence of 1821, Mahmud II (1808-39) set in motion a plan to revive Selim's Nizamı Cedid army under a new name, Muallem Asakir-i Mansure-i Muhammadiye (Trained Victorious Soldiers of Muhammad), which was strategically chosen to preempt criticism from the state's religious authorities. ${ }^{111}$ After co-opting the key members of the religious elite as well as the residents of Istanbul, ${ }^{112}$ Mahmud ordered his artillery corps to destroy the Janissary barracks in Istanbul in June $1826 .{ }^{113}$

The destruction of the barracks and slaughter of many of their inhabitants, known as the "Auspicious Event," made it possible for Mahmud to initiate comprehensive reforms throughout the armed forces. ${ }^{114}$ The reforms came too late, however. The Ottomans had already "missed" the revolution of the sixteenth and seventeenth centuries, and they lacked the organizational, financial, and technological capabilities to adopt the innovations associated with nineteenth-century modern warfare.

\section{Military Entrepreneurs, Mercenaries, and Military Reforms in Europe}

A comprehensive comparison between the Ottoman and European models would require a detailed analysis of multiple major European states. ${ }^{115}$ For

109. Uyar and Erickson, Military History of the Ottomans, p. 91.

110. The corruption and decay of recruitment, socialization, and career advancement mechanisms over the eighteenth century weakened the Janissaries' corporate identity. Arguably, the everincreasing political prowess of the Janissaries contributed to this outcome. The Janissaries used their political power to ask for further privileges from the sultan, allowing the corps to relax its recruitment and training standards. The Janissaries were also able to deter sultans from interfering in their internal affairs, which then facilitated corruption within the corps.

111. Finkel, Osman's Dream, pp. 432-439.

112. Aksan, "Military Reform and Its Limits in a Shrinking Ottoman World," p. 127; and Aksan, Ottomans and Europeans, p. 175.

113. The Artillery corps, which did not compete with the Janissaries, was the most modernized unit among the Ottoman forces, and its loyalties were not tied inextricably with the Janissary corps. See Aksan, Ottomans and Europeans, p. 127.

114. Ralston, Importing the European Army, pp. 55-78.

115. As for the identity of these states, I follow the conventional wisdom: Spain, France, Austria, 
the sake of simplicity, I instead highlight the historical commonalities within the general European approach to the production of military power, as epitomized in the French example, from the sixteenth century to the eighteenth century.

\section{THE LATE ARRIVAL OF EUROPEAN STANDING ARMIES}

The argument that European great powers formed institutionally strong central armies with intraorganizational unity and group cohesion relatively late is at once controversial and commonsensical. It is controversial in the sense that some scholars may argue, for example, that the origins of the modern French army go back earlier to Charles VIII's invading army to Italy in 1496. Two points need to be made. First, although it may be tempting to trace the modern French army to the fifteenth century, the military institutions and practices that are associated with modern armies rose to prominence only from the midseventeenth century onward. ${ }^{116}$ Second, the French standing army of the 1500s was institutionally "strong" only when compared with other European militaries of the time but, as the comparative analysis offered in this article highlights, it was considerably weaker than its Ottoman counterpart. ${ }^{117}$

Given these arguments, I posit that it is more appropriate to trace the emergence of strong central armies in Europe to Louis XIV's France in the second half of the seventeenth century. In fact, following the conventional wisdom on the impacts of the Revolutionary and Napoleonic Wars on the rise of the modern armies involving recruitment, socialization, and career advancement strategies, it is commonsensical to suggest that standing armies that professed a strong corporate identity, or well-established institutional practices and internal cohesion, reached maturity only around the end of the eighteenth century, if not later. ${ }^{118}$

and England/Britain from the 1490s onward; the Netherlands and Sweden from the 1590s onward; and Prussia from the 1640s onward. See Thompson and Rasler, "War, the Military Revolution(s) Controversy, and Army Expansion." For historical comparisons across the European cases, see Michael Duffy, The Military Revolution and the State, 1500-1800 (Exeter, U.K.: University of Exeter Press, 1980); James Raymond, Henry VIII's Military Revolution: The Armies of SixteenthCentury Britain and Europe (London: Tauris Academic Studies, 2007); and Olaf Van Nimwegen, The Dutch Army and the Military Revolutions, 1588-1688 (Woodbridge, U.K.: Boydell, 2010).

116. In addition, "the French army stayed at roughly the same size from 1445 to 1635." See Lynn, "Trace Italienne and the Growth of Armies," p. 319. See also David Parrott, Richelieu's Army: War, Government, and Society in France, 1624-1642 (Cambridge: Cambridge University Press, 2001), pp. 554-555.

117. Murphey, Ottoman Warfare, p. 19.

118. Posen, "Nationalism, the Mass Army, and Military Power." 
Why did the European states take so long to build such armies, and how did this "lateness" affect these armies' bargaining powers? Answering both questions requires an analysis of the ways in which military power was produced in Europe. Unlike the Ottomans, who created a large and permanent central army for their war-making efforts, European rulers relied heavily on "rented" military power via military entrepreneurs, in addition to hiring mercenaries or making other forms of contractual arrangements until the Revolutionary and Napoleonic Wars. ${ }^{119}$

Reliance on contractual actors for producing military power became a widespread practice in the Italian city-state system in the fourteenth and fifteenth centuries. Beyond Italy, production of military power in the rest of western and central Europe was still associated with the same feudal order that had dominated Europe for centuries, with mercenaries, or private military forces, playing an important part in states' war-making efforts. ${ }^{120}$ The rise of modern states-most notably, England, France, and Spain during the late fifteenth and sixteenth centuries-further institutionalized the reliance on mercenaries and contracted forces. Even though the conventional wisdom suggests that the modern state's arrival signaled a turn toward standing professional armies, mercenaries were also becoming more important. In "sixteenth-century France," V.G. Kiernan argues, the state "came to depend to a very remarkable degree on foreign mercenaries." ${ }^{\prime 21}$ In 1558, for example, 70 percent of the French army comprised German and Swiss troops. ${ }^{122}$

Arguably, three reasons lay behind European rulers' heavy reliance on private forces, foreign mercenaries, and other contractual arrangements. The first was necessity. The growing importance of firearms and artillery rendered feu-

119. Janice E. Thomson, Mercenaries, Pirates, and Sovereigns: State-Building and Extraterritorial Violence in Early Modern Europe (Princeton, N.J.: Princeton University Press, 1994), p. 9; and Deborah Avant, "From Mercenary to Citizen Armies: Explaining Change in the Practice of War," International Organization, Vol. 54, No. 1 (Winter 2000), pp. 41-72. Note that, in her research on banditry and state formation in the Ottoman Empire, Karen Barkey uses the term "mercenary" to include native seasonal troops, such as the peasant militias and similar native auxiliaries discussed in this article. See Barkey, Bandits and Bureaucrats: The Ottoman Route to State Centralization (Ithaca, N.Y.: Cornell University Press, 1994). According to Murphey, the fact that the Ottomans had already established a centralized military system made reliance on mercenaries (as the term is used in the scholarship on European military history) unnecessary. See Murphey, "Ottoman Military Organization," p. 139.

120. Black, European Warfare, 1494-1660, p. 13.

121. V.G. Kiernan, "Foreign Mercenaries and Absolute Monarchy," Past and Present, No. 11 (April 1957), p. 68.

122. David Parrott, "From Military Enterprise to Standing Armies: War, State, and Society in Western Europe, 1600-1700," in Tallett and Trim, European Warfare, 1350-1750, p. 80. 
dal armies obsolete. Second, using mercenaries and contractual forces made practical sense, because they "were combat-ready professionals who could be deployed wherever and whenever a ruler desired, provided he could pay them. ${ }^{\prime 123}$ Accordingly, rulers could avoid the financial and administrative burdens associated with raising and sustaining a permanent army that they would need only from time to time. ${ }^{124}$ Third, European rulers, similar to Ottoman sultans, were trying to find a balance between addressing geopolitical challenges and establishing and maintaining their domestic authority. Unlike the Ottomans, European rulers preferred contractual arrangements with "outside" actors, because they "lessened [monarchs'] dependence on the native nobles and towns which often opposed [their] attempts at centralization." ${ }^{125}$ Thus, contractual arrangements, despite their disadvantages such as unreliability during battles, "had the great merit of being politically safe."126

Reliance on private providers of military power and contractual arrangements peaked in the seventeenth century. As David Parrott's groundbreaking study on the role of the "military enterprise" in early modern Europe highlights, the ever-centralizing fiscal-military state of the seventeenth (and even eighteenth) century was more myth than reality; states made heavy use of "public-private partnerships" when producing military power. ${ }^{127}$ Furthermore, European rulers kept only the core of their standing armies on salary, increasing the number of troops in wartime by drawing on militia and foreign mercenaries. ${ }^{128}$ More than a third of Richelieu's army in 1636, for example, was composed of foreign mercenaries, and the military entrepreneur Bernard of Saxe-Weimar contributed to French war efforts with 20,000 foreign troops. ${ }^{129}$ This trend was not limited to France. The majority of rank-and-file in the Dutch field forces to which Maurice of Orange introduced the practice of drilling was composed of foreigners. ${ }^{130}$ The Swedish warrior-king Gustavus Adolphus, known for his low opinion of foreign mercenaries, was no excep-

123. Kiernan, "Foreign Mercenaries and Absolute Monarchy," p. 68.

124. William L. Urban, Bayonets for Hire: Mercenaries at War, 1550-1789 (London: Greenhill, 2007), p. 41.

125. Peter Wilson, "European Warfare 1450-1815," in Black, War in the Early Modern World, p. 186; and Urban, Bayonets for Hire, p. 41.

126. Kiernan, "Foreign Mercenaries and Absolute Monarchy," p. 69

127. David Parrott, The Business of War: Military Enterprise and Military Revolution in Early Modern Europe (Cambridge: Cambridge University Press, 2012).

128. Black, Beyond the Military Revolution, p. 179.

129. Colin Jones, "The Military Revolution and the Professionalization of the French Army under the Ancien Régime," in Clifford J. Rogers, ed., The Military Revolution Debate: Readings on the Military Transformation of Early Modern Europe (Boulder, Colo.: Westview, 1995), pp. 149-167.

130. Gunther E. Rothenberg, "Maurice of Nassau, Gustavus Adolphus, Raimonda Montecucccoli, and the 'Military Revolution' of the Seventeenth Century," in Peter Paret, ed., Makers of Modern 
tion; as of 1631, "foreign troops constituted the bulk of [his] army and did most of the fighting." 131

As Parrott has documented, this military outsourcing took more complex forms than the conventional wisdom suggests. ${ }^{132}$ Top officers in the standing army also raised self-contained military units, even armies, through private means, fueling an "enterprise system"133 that itself could be defined as "semientrepreneurship." ${ }^{134}$ In Parrott's words, "If the seventeenth century was 'the age of the soldier,' it was no less the age of the military contractor."135 Some of these military contractors were not only "employees" but also creditors to the sovereign, lending money to raise, feed, clothe, equip, and train troops for wars. ${ }^{136}$ The Thirty Years' War, in this context, produced Albrecht von Wallenstein and the count of Tilly, who were not only commanders of quasiprivate armies that grew to 80,000 troops in wartime, but also "great entrepreneur[s] of war." ${ }^{137}$ The war also produced harmful consequences of relying too much on private contractors.

An example of this was the extreme level of uncontrolled and uncontrollable violence and brutality, ${ }^{138}$ epitomized in the sack of Magdeburg in 1631 by Tilly's forces. Another consequence was the growing political clout of the private military commanders, exemplified by the rise and fall of Wallenstein. By the early 1630s, Wallenstein had become a key figure in European politics, allowing him to consider establishing his own princedom or even take over an existing one. ${ }^{139}$ To deal with the threat, the Holy Roman emperor, Ferdinand II, authorized Wallenstein's assassination in $1634 .{ }^{140}$

Following the Peace of Westphalia in 1648, European monarchs intensified

Strategy: From Machiavelli to the Nuclear Age (Princeton, N.J.: Princeton University Press, 1986), p. 41.

131. Ibid. According to Parrott, up to 90 percent Swedish forces were composed of Scottish and German mercenaries. See Parrott, The Business of War, p. 18.

132. Parrott, The Business of War.

133. Parrott, Richelieu's Army, pp. 549-550.

134. David Parrott, "Cultures of Combat in the Ancien Regime: Linear Warfare, Noble Values, and Entrepreneurship," International History Review, Vol. 27, No. 3 (September 2005), p. 525.

135. Ibid., p. 526. Note that the individual mercenaries were also transforming from the typical Landsknechte, or free soldiers, of the sixteenth century, to the more disciplined and professional mercenaries of the seventeenth century. See Olaf Nimwegen, "The Transformation of Army Organisation in Early-Modern Western Europe," in Tallett and Trim, European Warfare, 1350-1750, pp. 162-171.

136. Parrott, "From Military Enterprise to Standing Armies," p. 75.

137. Parrott, "Cultures of Combat in the Ancien Regime," p. 525.

138. Black, Beyond the Military Revolution, p. 176.

139. McNeill, The Pursuit of Power, p. 121.

140. One can easily argue that a similar "solution" would not have worked in the Ottoman case, where it was the Janissary corps, not an individual commander, who posed the challenge. 
their efforts at increasing the number of full-time professional troops and officers in their armies. The monarchs paid closer attention to the establishment of standardized and permanent regiments as well as the creation of "military communities" that excluded females and children. ${ }^{141}$ Reliance on private actors, foreign mercenaries, and other forms of contractual arrangements, however, remained an important component of producing military power throughout the course of the eighteenth century. The first half of the eighteenth century, for example, witnessed the flourishing of the Kompaniewirtschaft, where the captain was operating as a "businessman-investor" who "offered a traditional style of military proprietorship, in which capital investment and good management were a means to a decent profit over the life of the unit."142 Even Fredrick the Great (1740-86), known for mobilizing significant resources from the populations he ruled to support his war efforts, made extensive use of mercenaries and foreign troops, who, at times, constituted the majority of his forces. ${ }^{143}$ Habsburg armies that did much of the fighting against the Ottomans similarly depended largely on military entrepreneurs as well as foreign auxiliaries. ${ }^{144}$ Thus, while the conventional wisdom paints an ideal standing army associated with an "absolute" state, recent research on early modern military history suggests that "the spirit of Wallenstein," which exemplifies the military entrepreneur of the seventeenth century, "looms more heavily over the [eighteenth-century] armies of Eugen, Vendome, and Marlborough than has been allowed." 145

THE MILITARY'S BARGAINING POWER IN EARLY MODERN EUROPE

What does this summary suggest about central armies' bargaining powers and European states' response to the military revolution? In Europe, these bargaining powers were almost nonexistent. The central army possessed neither the corporate identity nor the ability to influence rulers' political survival cal-

141. John A. Lynn, "Forging the Western Army in Seventeenth-Century France," in MacGregor Knox and Williamson Murray, eds., The Dynamics of Military Revolution, 1300-2050 (Cambridge: Cambridge University Press, 2001), pp. 50-51.

142. Parrott, "From Military Enterprise to Standing Armies," p. 94.

143. Fredrick openly championed drawing upon contractual forces. Frederick II, The Refutation of Machiavelli's Prince; or, Anti-Machiavel, trans. Paul Somino (Athens: Ohio University Press, 1981), p. 84. Note, however, that from the mid-eighteenth century onward there was also a trend toward increasing bureaucratic control over mercenaries. See Jones, "The Military Revolution and the Professionalization of the French Army under the Ancien Régime," p. 160.

144. Aksan, Ottomans and Europeans, p. 84; and Faroqhi, The Ottoman Empire and the World around It, p. 102.

145. Parrott, "From Military Enterprise to Standing Armies," p. 95. 
culus. ${ }^{146}$ The explanation for the weak association between Europe's militaries and ruler survival is multifaceted. For one, European rulers stationed the bulk of their standing armies outside their capital cities, limiting their influence on palace politics. Moreover, succession mechanisms-which drew on primogeniture, dictating that the oldest child of a monarch would inherit the throne-left little opportunity for European militaries to emerge as king makers. Also, officers in European armies came from the nobility and had little incentive to undermine their monarchs' authority, given their intertwining fortunes. ${ }^{147}$

Most important, historical timing played a crucial role in the weak association between armed forces and rulers' political survival calculus. When the Janissary corps was created, Ottoman political, administrative, and bureaucratic institutions were in their nascency. Under these circumstances, the military and civilian institutions evolved together, allowing the central army to "lock in" disproportionate influence over rulers' political survival calculus. In Europe, central armies with strong institutional practices and intraorganizational unity had been introduced by the mid-seventeenth century, only after institutionalization in administrative, bureaucratic, and political spheres had reached a certain level of maturity, an accomplishment that did not entail disproportionate concessions to the military. ${ }^{148}$

In addition, the corporate identity of Europe's militaries was considerably weak even during the seventeenth and eighteenth centuries, especially when compared with those of the Janissary corps and nineteenth-century modern armies. This weakness had a lot to do with the particular recruitment, socialization, and career advancement mechanisms employed by European rulers between the 1500s and the French Revolution. Even before socialization mechanisms came into play, recruitment strategies guaranteed that the degree to which the members of the military could define themselves vis-à-vis the corps,

146. In Europe, there existed no case of direct threat to ruler survival from within the military that was comparable to the Ottoman experience, until the rise of Napoleon. Parrott argues that the Fronde of 1648-1653 could potentially be seen as a threat from within the military, as many nobles who were associated with the uprisings had military affiliation. It would, however, be a stretch to frame the Fronde as a threat posed by the armed forces to the political survival of the king. See ibid., p. 87.

147. André Corvisier, Armies and Societies in Europe, 1494-1789 (Bloomington: Indiana University Press, 1979), pp. 87-105.

148. On how the administrators eventually exerted their powers over military officers, especially in France, Spain, Austria, Piedmont, and Bavaria, see ibid., pp. 73-77. In France, this civilian control was established through the so-called Intendant, who personified strong central [read civilian] control over the army. On this dynamic, see Jones, "The Military Revolution and the Professionalization of the French Army under the Ancien Régime," pp. 157-159. 
and each other, would remain limited. ${ }^{149}$ Apart from reliance on foreign mercenaries, the European armies of the time also drew heavily on press gangs and similar methods for military recruitment, suggesting that the process was hardly selective. ${ }^{150}$

Socialization mechanisms, in turn, were at best intermittent and insufficient to create a sense of belonging. ${ }^{151}$ The period in question also preceded the advent of nationalism. Without state efforts to standardize culture and language through education and nationalistic indoctrination, European armies until the French Revolution remained remarkably heterogeneous, especially when compared with the Ottoman central army where linguistic, national, and religious homogeneity was engineered through strict institutional practices. ${ }^{152}$ Of equal importance was the chasm between officers and the rest of the fighting forces. Coming from the nobility, officers had much more in common with their monarchs (and even with officers in competing armies) than they did with the soldiers under their command, a factor that limited the extent to which the standing army could profess a distinct, unitary corporate identity. Further, career advancement mechanisms were based on nepotism, which deepened the rift between the officers and noncommissioned officers as well as recruits, who all had many reasons to feel disassociated from each other and have very little incentive to define their loyalties with respect to a common institution. ${ }^{153}$ Consequently, even when the size of the permanent full-time staff increased, the change in numbers did not necessarily translate into a more salient corporate identity and amplified bargaining powers vis-à-vis rulers.

THE EUROPEAN STATES AND THE MILITARY REVOLUTION

So, how did the limited bargaining power of European armed forces affect states' responses to military revolution? The answer is well documented. While European armies "did not all march in lock-step along the evolutionary path," the great powers of Europe closely interacted with each other with re-

149. On recruitment processes in European armies, see Corvisier, Armies and Societies in Europe, 1494-1789, pp. 41-46; and Parker, Beyond the Military Revolution, pp. 174-180.

150. Avant, "From Mercenary to Citizen Armies"; and Anthony Mockler, The Mercenaries (New York: Macmillan, 1970), pp. 105-129.

151. Posen, "Nationalism, the Mass Army, and Military Power."

152. Ernest Gellner, Nations and Nationalism (Ithaca, N.Y.: Cornell University Press, 1983); and Posen, "Nationalism, the Mass Army, and Military Power."

153. There were also numerous cases of foreign commanders, such as Prince Eugene of Savoy and Luigi Fernando Marsigli, both of whom served in the Habsburg army. See Faroqhi, Ottoman Empire, p. 104. 
gard to military reforms, serving as active participants of the so-called military revolution. ${ }^{154}$ In this reading, the military revolution is best conceptualized as a process where European rulers promoted interaction between different paradigms, creating synergies that propelled further military innovations in tactics and force deployment. Doing so, European rulers were driven by concerns about improving battlefield effectiveness and — as this article highlights - they were not constrained by the parochial interests of their militaries. As a result, in Black's words, "Western European elites were willing to co-operate with military change ... to a greater extent than elsewhere."155

The diffusion of drill, which involved systemic rehearsals of complex military maneuvers and an emphasis on rigorous training and discipline, is illustrative. Highlighted by Roberts as one of the most important components of the military revolution, drill, with which Eric IV of Sweden began experimenting during the course of the 1560s, was institutionalized by Maurice of Nassau in the late sixteenth century and allowed Dutch forces "speedy manoeuvre and a hitherto unknown rate of fire." 156 The practice was then perfected by Gustavus Adolphus of Sweden, whose success at defeating Tilly's forces in 1631 gained him recognition across Europe. Impressed with the tactical effectiveness that accompanied drill, which was also spreading especially in northern Germany, Louis XIII imported the practice as well as techniques associated with it. Louis XIV, in turn, showed an "intense interest" in drill and improved upon the practice through rigorous training and disciplinary action, even personally leading the relevant exercises. ${ }^{157}$

It was not only the rulers but also the military entrepreneurs and individual officers who played an important role in the military revolution. Different from the Ottoman case, where the Janissaries sustained a near-oligopoly over the production of military power for centuries, the market for force in seventeenth-century Europe was highly competitive and truly internationalized. During the course of the Thirty Years' War, for example, there were around 1,500 individuals who owned regiments in Europe. ${ }^{158}$ The availability of alternative suppliers of military expertise fueled competition and facilitated

154. Lynn, "The Evolution of Army Style in the Modern West, 800-2000," p. 508; and David Eltis, The Military Revolution in Sixteenth-Century Europe (London: Tauris Academic Studies, 1995), p. 8.

155. Black, Beyond the Military Revolution, p. 186.

156. Lynn, "Forging the Western Army in Seventeenth-Century France," p. 48.

157. Ibid.

158. Geoff Mortimer, "War by Contract, Credit, and Contribution: The Thirty Years' War," in Geoff Mortimer ed., Early Modern Military History, 1450-1815 (Basingstoke, U.K.: Palgrave Macmillan, 2004), p. 104. 
the dissemination of military knowledge, further energizing and accelerating the military revolution. ${ }^{159}$

\section{Potential Criticisms}

The present study can be criticized on at least three grounds. The first potential critique is also the most obvious: the European and Ottoman experiences are too different to warrant comparison. This critique is also associated with the conventional wisdom on the Ottomans' place in global history, which presents the Ottoman state as either an essentially Oriental-Islamic entity or a "unique" political creature that "belonged wholeheartedly to neither [the Middle East nor Europe]." ${ }^{160}$ Emerging historiography on the Ottomans, however, points toward a more nuanced perspective, suggesting that European states and the Ottomans, as they cohabited "a common world," were essentially comparable until at least the eighteenth century. ${ }^{161}$ One could also argue for comparability especially in the military sphere, because it constituted the most salient point of interaction. ${ }^{162}$

A second concern may focus on the external validity of the arguments contained in this article, ${ }^{163}$ especially with respect to historical timing and the importance of military organizations as veto players. While further research is necessary, it is possible to suggest that the theoretical framework can address cases beyond the Ottoman Empire and Europe. The Russian case is illustra-

159. Parrott, "From Military Enterprise to Standing Armies," p. 84. On motives of the military enterprisers, see Parrott, The Business of War, pp. 241-259. See also Black, Beyond the Military Revolution, p. 4; and Ágoston, "Empires and Warfare in East-Central Europe, 1550-1750," p. 112.

160. Wheatcroft, The Ottomans, p. xxviii.

161. Faroqhi, The Ottoman Empire and the World around It, pp. 25-26, 211; and Goffman, The Ottoman Empire and Early Modern Europe.

162. Levy, "Military Reform and the Problem of Centralization in the Ottoman Empire in the Eighteenth Century," p. 227. Also, note that of the forty-three wars that the Ottomans fought from 1463 to 1918, thirty-one were with European states. See Quataert, The Ottoman Empire, 1700-1922, p. 85.

163. On the question of internal versus external validity in macrohistorical comparisons, see Dan Slater and Daniel Ziblatt, "The Enduring Indispensability of the Controlled Comparison," Comparative Political Studies, Vol. 46, No. 10 (October 2013), pp. 1301-1327. Also note that, in line with the arguments made in this article, the Ottomans had a much easier time with reforms in the navy as well as with importing technology. On military technology and the Ottomans, see Ágoston, Guns for the Sultan, p. 204; Ágoston, "Empire and Warfare," p. 114; Tuck, "'All Innovation Leads to Hellfire,'" p. 484; and Jonathan Grant, "Rethinking the Ottoman 'Decline': Military Technology Diffusion in the Ottoman Empire, Fifteenth to Eighteenth Centuries," Journal of World History, Vol. 10, No. 1 (Spring 1999), p. 200. This dynamic is essentially consistent with the arguments suggesting internal validity: Janissaries blocked reforms only in areas where they felt they would be threatened, allowing the sultans to seek reforms in other areas. 
tive. ${ }^{164}$ Russia's response to the military revolution, though slower than that of western European states, constituted a success story when compared with the Ottoman experience, for the relevant reforms empowered the Russian state at the expense of not only the Ottomans but also Sweden (during the course of the Great Northern War of 1700-21). ${ }^{165}$ So, is it possible to extrapolate from the Ottoman-European experiences to explain the timing and success of Russia's response to military revolution?

The preliminary answer is yes. The early modern Russian military system contained a counterpart to the Janissaries, the so-called Streltsy, which was formed in the mid-sixteenth century as an elite group of guardsmen specializing in firearms. Similar to the Janissaries, its numbers increased during the course of the seventeenth century (from 33,775 in 1632 to more than 50,000 in 1681) despite its decreasing military value. ${ }^{166}$ Like the Janissaries, over time, it emerged as a "powerful social caste and political pressure group."167 Well aware of its waning military significance, the Streltsy eventually became "the main obstacle to [Peter the Great's] army reorganization," in particular, and champions of "opposition to Europeanization," in general. ${ }^{168}$ Peter was able to destroy the Strelsy when its members mutinied in 1698, which then allowed him to move forward with structural military reforms.

Third, the article can be criticized for its geographical and temporal scope, which cuts across centuries as well as continents and a wide variety of political systems. By offering broad generalizations, one can argue, the theory and narrative offered here omit many important details and oversimplify, or even distort, many others. ${ }^{169}$ These charges can be countered on two grounds. First, the present study offers a self-contained answer to a specific question. It does not seek to explain why the Ottomans "declined," why or how the West bested the rest, or the origins of democratic regimes, but instead deals primarily with different responses to the military revolution in the Ottoman Empire and Europe. Second, although it is true that there may be costs and sacrifices associated with macrohistorical generalizations and comparisons, the benefits to be ac-

164. Ágoston, "Military Transformation in the Ottoman Empire and Russia, 1500-1800."

165. Brian L. Davies, Empire and Military Revolution in Eastern Europe: Russia's Turkish Wars in the Eighteenth Century (London: Continuum, 2011).

166. Ágoston, "Military Transformation in the Ottoman Empire and Russia, 1500-1800," p. 301.

167. Ibid., p. 307.

168. Benedict Humphrey Sumner, Peter the Great and the Ottoman Empire (Oxford: Basil Blackwell, 1949), p. 9.

169. James Mahoney and Dietrich Rueschemeyer, eds., Comparative Historical Analysis in the Social Sciences (Cambridge: Cambridge University Press, 2003). 
crued by tackling big questions from a unified perspective may justify the undertaking, not only for the insights it offers, but also for the new questions it raises.

\section{Conclusion}

This article has proposed a theoretical framework that explores different patterns in states' responses to military innovations and offers counterintuitive insights into the relationship between the institutional strength of military organizations and production as well as diffusion of military power in the context of the early modern European and Ottoman experiences. It also makes three further contributions to international relations literature. First, discussion of the relationship between civil-military relations points toward a novel, if intuitive, theory of the bargaining powers of the military. Devised in terms of two dimensions-salience of corporate identity and centrality to ruler's political survival calculus-this framework can be utilized to address numerous research questions that go beyond responses to military innovations. For example, it can help explore why some rulers, exemplified by Libya's Muammar al-Qaddafi, consciously allow military institutions and cohesion within the corps to decay, while others in seemingly similar positions-for example Syria's Bashar al-Assad-do not. ${ }^{170}$

A second potential contribution involves the roles that private military actors can play during state-building processes in weak or failing states. The conventional wisdom on private providers of security and military functions, which can be traced to Niccolò Machiavelli, is that they are unreliable, perform poorly on the battlefield, and lead to numerous problems involving control as well as accountability. The conventional wisdom also suggests that reliance on such actors only facilitates and perpetuates "the rot in the internal governance process," especially in weak or failing states, implying that such reliance exacerbates problems associated with state formation. ${ }^{171}$

The historical analysis offered in this article raises questions about the con-

170. One preliminary answer is that the Assad family was able to utilize al-Muhabarat, Syria's formidable secret service, to sever the link between the armed forces and the dynamics of political survival, making it possible to build an army that was institutionally strong without becoming hostage to it. Unable or unwilling to draw upon such an institutional "cushion," Qaddafi arguably preferred a weak army, because an army with a strong corporate identity could eventually emerge as a threat to his rule in Libya's weakly institutionalized political setting.

171. Abdel-Fatau Musah, "Privatization of Security, Arms Proliferation, and the Process of State Collapse in Africa," Development and Change, Vol. 33, No. 5 (November 2002), p. 912. 
ventional wisdom, hinting at the possibility that rulers' heavy reliance on contractual troops and military entrepreneurs-especially during the initial phases of state building-shielded European states from a problem that bedeviled many polities elsewhere in the world, including the Ottoman Empire: the long shadow of armed forces in politics. Under certain circumstances, then, rulers can rely on private providers of military power to build strong civilian institutions without having to concede significant bargaining leverage, or becoming hostage, to the armed forces. ${ }^{172}$ This insight does not negate the essential disadvantages associated with private providers of organized violence. Following a number of recent studies on private military actors, however, ${ }^{173}$ it raises new questions about the short-term versus long-term costs and benefits of reliance on private military actors in the context of a challenge-establishing long-lasting and stable institutions in weak or failing states-that has long proven resilient to conventional paradigms and strategies.

Finally, this article joins a number of recent entries to the literature that aim to move away from the tendency to treat the European/Western experience as the norm (and, by implication, non-Western experiences as anomalies) and toward theoretical frameworks that account for variation in institutional design as well as international behavior through a unified perspective. ${ }^{174}$ The comparative approach offered in this article contributes to scholars' understanding of international politics in two ways. First, as Edward Keene forcefully argues, the origins of the present-day global political order cannot be reduced to a story involving the rise of the Westphalian system and its spread to the rest of the world through a linear process. ${ }^{175}$ The Western states interacted not only with each other but also with the extra-Westphalian polities, and it is through this interaction that the present-day global order arose. In this context, incorporating the Ottoman Empire-Europe's closest "other"176_into the theory

172. For compatible perspectives, see S.E. Finer, The Man on the Horseback: The Role of the Military in Politics (London: Pall Mall, 1969), p. 6; and Donald L. Horowitz, Coup Theories and Officers' Motives: Sri Lanka in Comparative Perspective (Princeton, N.J.: Princeton University Press, 1980), pp. 6-15. 173. See, for example, James Pattison, "Outsourcing the Responsibility to Protect: Humanitarian Intervention and Private Military and Security Companies," International Theory, Vol. 2, No. 1 (March 2010), pp. 1-31.

174. Hui, War and State Formation in Ancient China and Early Modern Europe; and Ferejohn and Rosenbluth, War and State Building in Medieval Japan.

175. Edward Keene, Beyond the Anarchical Society: Grotius, Colonialism, and Order in World Politics (Cambridge: Cambridge University Press, 2002).

176. Iver B. Neumann and Jennifer M. Welsh, "The Other in European Self-Definition: An Addendum to the Literature on International Society," Review of International Studies, Vol. 17, No. 4 (October 1991), pp. 327-348; Halil Inalc1k, "The Turkish Impact on the Development of Modern 
and historiography of international relations is not only desirable, but also essential to construct a more comprehensive understanding of the origins of the international system.

Second, juxtaposing the European approach to the production of military power during the early modern era with the alternative path followed by the Ottoman Empire, this study has aimed to contribute to scholars' understanding of not only the Ottoman case but also the European one. Doing so, this comparative approach highlights an additional benefit of expanding the geographical and temporal scope of mainstream international relations theory that has long focused-almost exclusively-on the so-called Westphalian state system: by looking beyond the Westphalian experiences, international relations scholars can see the same experiences in a new light, raising new questions and generating novel insights about the past and present of the international political orders.

Europe," in Kemal H. Karpat ed., The Ottoman State and Its Place in World History (Leiden, Netherlands: Brill, 1974), pp. 51-57; and Quataert, The Ottoman Empire, 1700-1922, pp. 6, 76. 